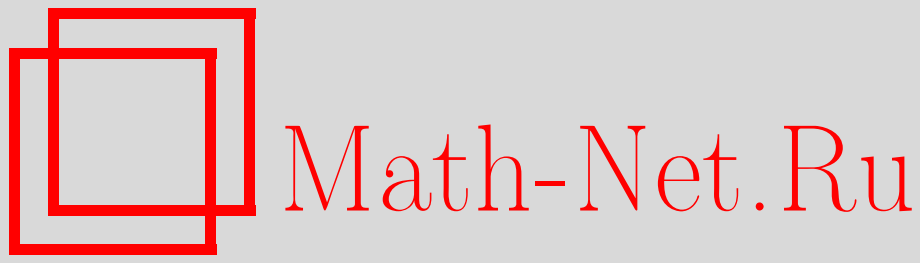

Виктор Борисович Лидский, Функи. анализ и его прил., 2009, том 43, выпуск 1, 1

DOI: https://doi.org/10.4213/faa2955

Использование Общероссийского математического портала Math-Net.Ru подразумевает, что вы прочитали и согласны с пользовательским соглашением

http://www . mathnet.ru/rus/agreement

Параметры загрузки:

IP : 35.173 .219 .12

26 апреля 2023 г., 18:00:55

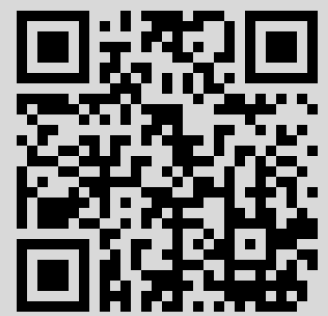




\section{Виктор Борисович Лидский}

29 июля 2008 г., после тяжелой продолжительной болезни, на 85-м году жизни скончался Виктор Борисович Лидский, замечательный человек и выдающийся математик, обогативший первоклассными результатами математическую физику и теорию операторов.

Войну Виктор Борисович закончил офицером разведки, был неоднократно награжден орденами и медалями.

Виктор Борисович вошел в математику с крупными достижениями. Путем тонких исследований периодических гамильтоновых систем он установил, что известные достаточные условия устойчивости являются и необходимыми. Он первым начал систематиче-

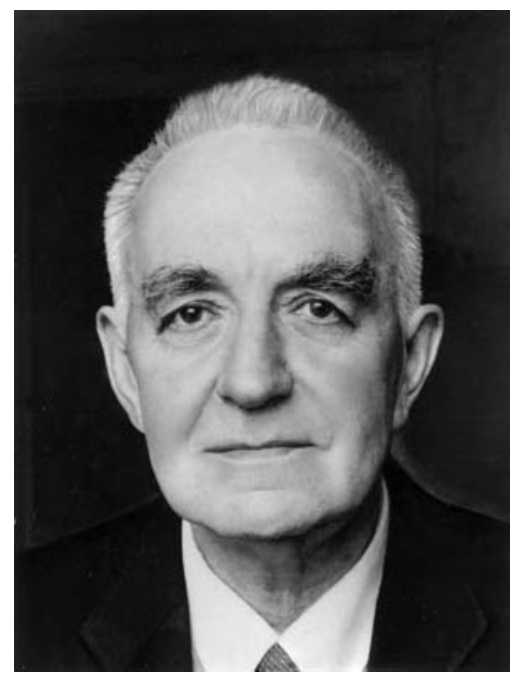
ское изучение спектральных свойств несамосопряженного оператора Штурма-Лиувилля. Классической является его теорема о совпадении матричного и спектрального следов ядерных операторов в гильбертовом пространстве. Предложенный им метод суммирования рядов Фурье по корневым векторам несамосопряженных операторов, который он назвал методом Абеля, теперь называют методом Абеля-Лидского.

Вместе с группой своих сотрудников Виктор Борисович исследовал спектр колебаний безмоментных оболочек, обнаружив участки непрерывного спектра. Он исследовал трудную проблему о колебаниях замкнутой оболочки в пространстве, заполненном вязкой жидкостью.

Виктор Борисович был энергичным, но скромным и отзывчивым человеком, его любили и уважали студенты и многочисленные аспиранты, и всем доставляло удовольствие находиться рядом и неформально общаться с ним.

Он знал и любил классическое искусство, его интересы вне математики также были весьма широки.

Виктор Борисович Лидский был активным членом редколлегии журнала со дня его основания и почти до последних дней своей жизни. Он навсегда останется в нашей благодарной памяти. 